Stock, Adam ORCID:

https://orcid.org/0000-0002-6172-0971 (2015) The Blind Logic of Plants: Enlightenment and Evolution in John Wyndham's The Day of the Triffids. Science Fiction Studies, 42 (3). pp. 433-457.

Downloaded from: http://ray.yorksj.ac.uk/id/eprint/1076/

The version presented here may differ from the published version or version of record. If you intend to cite from the work you are advised to consult the publisher's version: https://www.jstor.org/stable/10.5621/sciefictstud.42.3.0433?seq=1

Research at York St John (RaY) is an institutional repository. It supports the principles of open access by making the research outputs of the University available in digital form. Copyright of the items stored in RaY reside with the authors and/or other copyright owners. Users may access full text items free of charge, and may download a copy for private study or non-commercial research. For further reuse terms, see licence terms governing individual outputs. Institutional Repository Policy Statement

\title{
RaY
}

Research at the University of York St John

For more information please contact RaY at ray@yorksj.ac.uk 


\section{Adam Stock}

\section{The Blind Logic of Plants: Enlightenment and Evolution in John Wyndham's The Day of the Triffids}

By the time he was demobilized after the war, John Wyndham was desperate to publish a commercially successful novel that could reach beyond the limits of the then relatively small British science-fiction market. ${ }^{1}$ Success did not come for several years, but from the moment that The Day of the Triffids appeared as an abridged serial in the US weekly magazine Collier's as "Revolt of the Triffids" in early 1951, Wyndham reached beyond the traditional fan base into the cultural mainstream as few sf writers of his generation ever did. The popularity of Wyndham's walking carnivorous plants persists to this day, through the novel itself and through numerous translations and adaptations into films and television series, radio productions, and comics. ${ }^{2}$

One reason Wyndham was able to find such a large readership is that his postwar style was consciously influenced by H.G. Wells's early scientific romances (James 79). As even his fiercest critics acknowledge, Wyndham's prose "read[s] smoothly" (Aldiss, Billion 294). He adapted and updated Wells's themes to engage in a sophisticated but accessible manner with contemporary concerns and social anxieties surrounding the early Cold War, the retreat of the British Empire, and the growth of the welfare state. The generational and political division from Wells reflects Wyndham's experiences of World War II and its aftermath as well as their different social classes. I argue that The Day of the Triffids cements Wyndham's significance as a writer of socially engaged science fiction. While Wells professed himself a socialist, Wyndham's politics share strong affinities with the tradition of British liberal reformers such as John Stuart Mill, Herbert Asquith, and William Beveridge. ${ }^{3}$ Secular and liberal ideas are prominent throughout his postwar fiction.

A result of his smooth prose and liberal politics is that some of the unsettling and even macabre elements of novels such as The Day of the Triffids, The Kraken Wakes (1953), and The Chrysalids (1955) are easily glossed over. Because Wyndham was desperate for commercial success, the initial popularity of The Day of the Triffids can be ascribed in part to his willingness to bend to the wishes of publishers so that the text would achieve a wider circulation. There exist three significantly different versions of the novel that include changes to plot and thematic variations in addition to abridgment. Still, the changes among the three do not entirely result from commercial pressures. As Andy Sawyer argues, "Wyndham's textual changes are often a result of exploring the moral maps of his fiction" (11).

In this article, I analyze textual changes in different published versions of The Day of the Triffids in conjunction with archival material to shed greater light on the precise nature of Wyndham's relationship to Wells (which was far from the straightforward admiration of a devoted acolyte) and to suggest both 
his use of competing theories of evolution and his fears of genetic mutation. In so doing I counter a prevailing critical view that The Day of the Triffids is a "cosy catastrophe," which, to quote Brian Aldiss, is "totally devoid of ideas" (294). While the question of whether the novel is "cosy" has recently been re-examined, I also argue that the term "postapocalypse" is more accurate than "catastrophe" and explore the liberal politics of Wyndham's postapocalyptic landscape. ${ }^{4}$ The novel deals more extensively with shifting social and political values than with specific policies; and the triffids highlight the assumptions and values on which scientific, supposedly value-free evolutionary theories are based. In particular, early Cold War fears of nuclear holocaust and the anti-Communist hysteria that Joseph McCarthy had begun to provoke in the US operate as two distinct menaces that are important reference points for the development of social and political values in the novel. These values do not always accord with Wyndham's reformist modern liberalism, and hence the triffids can be seen as a challenge Wyndham set himself in order to explore the continuing relevance of such beliefs in the context of the unprecedented terrors and cruelties of his age. This tension, which Wyndham purposefully sets out to explore and never attempts to minimize or suppress, is noticeable across what David Ketterer has termed Wyndham's "facts of life sextet" but is particularly apparent in The Day of the Triffids (1951), The Kraken Wakes (1953), The Chrysalids (1955), and The Midwich Cuckoos (1957). ${ }^{5}$ For this reason, my discussion has wider significance in terms of Wyndham's postwar fiction as a whole, forming a context for the popularity of his 1950 s novels in the UK.

Adapting Wells: Wyndham's Postwar Style and Themes. The Day of the Triffids represented a noticeable change in style from Wyndham's prewar output. Seeking to distance himself from his genre fiction, which he had mostly written under the names John Beynon Harris and John Beynon, the man born John Wyndham Parkes Lucas Beynon Harris restyled himself as John Wyndham. ${ }^{6}$ His new persona was consciously more Wellsian: Wyndham invoked Wells as his literary forebear in several published and unpublished articles, interviews, and questionnaires from this period; he made overt and covert references to Wells in The Day of the Triffids and in other postwar novels. At its best, the easy elegance of Wyndham's prose is reminiscent of some of Wells's early scientific romances. As Ketterer notes, Wyndham adopts a style of life writing or "documentary realism" reminiscent of Wells (“'Vivisection”" 305) . T The first-person narrator William Masen, like Wells's Time Traveller, positions his account as "a personal story" that "joins up with" those of other survivors in a larger work of written history for the benefit of subsequent generations (The Day of the Triffids, Penguin ed., hereafter $D T, 233$ ). In thematic terms, the focus on biology, social relations, and unconventional familial relationships (at least by the standards of his own day) also owes some debt to H.G. Wells. At the narrative level, meanwhile, The Day of the Triffids, like Wells's The War of the Worlds (1898) and The Invisible Man (1897), begins with a seismic change in the conditions of life 
and follows through logically the challenges and obstacles that the main characters face due to this altered state of affairs in an otherwise everyday landscape.

Wells evidently was for Wyndham a model writer, one who had retained a wide readership and commercial success. Yet it would be reductive to put his success entirely down to an appropriation of Wellsian techniques and concerns. Also important was Wyndham's experience of the Blitz in London's Bloomsbury district and his service in the British Army as it advanced across Western Europe following D-Day, which had a profound effect on his outlook. As Barry Langford puts it, "Wyndham had lived through and been appalled by the carnage of war; in The Day of the Triffids he records his disillusion with the world his generation fought to realize" (DT xvi). The novel was written against the backdrop of a postwar redevelopment that Wells did not live to see. Moreover, for many years Wyndham's treatment of Wells had been frequently critical, playful, or ironic. Even in his early novel Planet Plane (published as by John Beynon in 1935, re-published as Stowaway to Mars by John Wyndham in 1972), a journalist in the Mars-bound crew rhetorically asks, "Do you remember the monstrous crabs which Wells's time traveller found in the dying world? Nasty chaps-I used to dream about them when I was a kid. If there are many of them, I doubt whether my devoted public will get a story at all" (103). Following Wells slavishly, Wyndham/ John Beynon seems to humorously suggest, would be a dead end for his writing.

In the opening scene of all three versions of The Day of the Triffids, Masen awakes alone in hospital. Drawing on a familiar trope in future fiction, the world has been transformed while he was sleeping. ${ }^{8}$ Overnight, the appearance of a fantastic display of green comets in the night sky has blinded most of the world's population, bringing chaos, destruction, and violence. As Matthew Moore points out, drawing on Ketterer ("The Facts of Life Sextet"), the comets are an ironic inversion of the celestial harbingers of reason in Wells's 1906 story In the Days of the Comet ("A Critical Study" 75-76; 78-88). In Wells's novel, the comets release a gas that causes the world's population to fall into a profound sleep, awakening with all of their petty jealousies and emotional irrationalism replaced by a calm sense of reason. In The Day of the Triffids, the green lights in the sky prefigure blindness, pandemic fatal disease, and ultimately the downfall of civilization itself.

Given that the novel opens on an estranged world of mass blindness, it would be easy to make the case that the introduction of walking poisonous plants to the plot is entirely superfluous. Wyndham himself felt this double disaster had led him into problems with critics. In a rare interview with the Saturday Times Review columnist "Pooter" (the penname of Alex Hamilton), Wyndham responded to critics who

crashed down on The Day of the Triffids. They invoked Wells's ruling that readers could only be asked to accept one fantastic thing. "I got fairly lambasted by the better-read. But, do you see, neither [the theme of "mobile 
vegetables' nor universal blindness] would work on its own.” (23; emphasis in original)

For Wyndham, mass blindness and the rampaging triffids work in tandem: the poisonous plants most often aim their whipping stings at the eyes (DT 37), while the comets wreak blindness on a global and indiscriminate scale, resulting in conditions which triffids can then exploit. He puts Wells's ruling on fantastic things to one side, but only to continue to operate in a Wellsian vein, based on the logical extrapolation of a fantastic premise. As far removed as triffids are from reality-or indeed as are any of the other fantastic phenomena in Wyndham's novels, from alien sea-monsters to telepathic mutant children and cloned Nazis in flying saucers-the (threatening) figures in Wyndham's fiction do not behave fantastically; their extrapolation from the original imaginative genesis follows a causal pattern of development along ifthen lines. (If ninety-nine percent of the population were blinded overnight, then the human population would collapse and species better adapted to the new environment would flourish.) Wyndham therefore saw his work as "logical fantasy" rather than "science fiction." He associated the former with H.G. Wells-in part because of his perception, in the interview cited above, that Wells asked his readers to only "accept one fantastic thing." Wyndham interpreted "science fiction" to mean hard sf, which he traced along a genealogy from Jules Verne's forensically detailed descriptive style to John W. Campbell's insistence that science fiction should accord with the latest knowledge of practicing scientists. ${ }^{9}$ Wyndham pointedly did not want to be associated with hard sf. By presenting himself as a literary descendant of Wells, however, he felt able to adapt formal techniques and generic conventions commonly identified as belonging to sf, such as invasion by a fantastic species. Hence his protagonist Bill Masen overtly refers to Wells's short story "In the Country of the Blind" (1904), in which a mountaineer finds himself prisoner of a blind tribe. He tells Josella Playton that "Wells imagined a people who had adapted themselves to blindness. I don't think that is going to happen here-I don't see how it can" (DT 66). The acknowledgment that The Day of the Triffids contains a Wellsian premise simultaneously hints that the narrative will play out quite differently. ${ }^{10}$

Chapter 2 of The Day of the Triffids is devoted to an external analepsis in which Masen dovetails his life story, including a career in biology on a triffid plantation, into a far longer and more significant discussion of the arrival of the triffids. It is here that Masen first positions his story as being "a personal record" for the benefit of future generations with no memory of the comets, reflecting that it "must be difficult for young people who never knew it to envisage a world like that. Perhaps it sounds like a golden age-though it wasn't quite that to those who lived in it" (DT 19). This estranged position gives Wyndham considerable space to engage in social and political critique of the postwar world. ${ }^{11}$ It is significant to his subsequent description of the triffids that this account opens with a history of the successful launching of satellite atomic and biological weapons, an "unknown number of menaces up 
there over your head, quietly circling until someone should arrange for them to drop" (DT 20). As I will explore further below, in both versions of the novel (but not the magazine serialization), the triffids, in parallel, are released into the atmosphere when a plane carrying a stolen box of seeds from a Soviet laboratory is shot down.

The seedpod was a frequent trope in 1950s science fiction for representing anxieties surrounding the power of the atomic bomb and the threat of Communist infiltration and invasion. Like a Communist cell, a seed may lie dormant for a long period before growing into a menace. ${ }^{12}$ It is significant in this regard that the sale of The Day of the Triffids to both Doubleday and Collier's in the spring of 1950 caught a rising tide of anti-Communism that can be traced back to Senator Joseph McCarthy's famous Lincoln's Day speech earlier that year in Wheeler, Virginia, in which he claimed to have evidence that 205 known Communists were working in the State Department. ${ }^{13}$ The seed is a traditional pastoral symbol of renewal and growth, but when exposed to radiation its springtime connotations can be perverted or mutated into something more subversively sinister. Seedpod imagery therefore proved especially fertile, if the pun may be excused, for alien invader movies such as Invasion From Mars (1953) and especially Invasion of the Body Snatchers (1956), which for David Seed is the example par excellence of "truly paranoid narratives," because of "the virtual impossibility of distinguishing simulation from original" among the town's inhabitants (134). In Wyndham's novel the triffid threat becomes similarly militarized through the image of a seedpod with murky origins. ${ }^{14}$ Wyndham provides strong hints that the triffid is a product of genetic mutation, and its seeds therefore tie together McCarthyist infiltration fears with anxieties over radioactive contamination. While this range of issues is historically specific to the postwar era, the influence of Wells can be seen in terms of method and the choice of an invented biological foe that enables Wyndham to engage with debates in evolutionary theory.

Adaption and Change: Three Versions of Triffids and the History of Evolution. The importance of the origins of the triffid seeds is underlined by changes in the text between the publication in Collier's magazine of an abridged serialization (Jan.-Feb. 1951) under the title "The Revolt of the Triffids" (hereafter referred to as $R T$ ) and later publications in novel form. Doubleday first published The Day of the Triffids in hardback in the US. (A mass-market paperback edition was released under their "Dolphin" imprint before the end of 1951, hereafter referred to as The Day of the Triffids [a] or $D T$ [a]). This novel is significantly different from the magazine story in both content and language, but it is also significantly abridged from the version of the novel subsequently published towards the end of 1951 in hardback by Michael Joseph in the UK. ${ }^{15}$ (A Penguin paperback following the Michael Joseph text subsequently appeared in 1954.) There are additional differences in language between the US and UK versions of the novel, which Wyndham had to "de-Americanize" for a British audience. The important changes in tone, voice, and content are apparent even in the opening sentences: 
Collier's (US): Take it from me: when a day that you happen to know is Wednesday starts off by sounding like Sunday, there is something seriously wrong somewhere. I felt that from the moment I woke. Yet, when I was a little wider awake, I doubted my own reactions.

Doubleday/Dolphin (US text): When a day that you happen to know is Wednesday starts off by sounding like Sunday, there is something seriously wrong somewhere.

I felt that from the moment I woke. And yet, when I started functioning a little more smartly, I became doubtful.

Michael Joseph/Penguin (UK text): When a day that you happen to know is Wednesday starts off by sounding like Sunday, there is something seriously wrong somewhere.

I felt that from the moment I woke. And yet, when I started functioning a little more sharply, I misgave.

These variant openings point to larger differences in narrative voice that are carried through each text. In the magazine version, the conversational cliché "Take it from me" indicates a certain confident swagger lacking from the two novel texts. The lack of a separate paragraph may be due to the publication layout, which uses two to four tight columns in small font and is broken up by adverts, cartoons, and illustrations. Likewise, alterations to the third sentence may have been made to decrease the word count, but they also simplify the voice and remove an element of personality that can be read into the more unusual expressions of the other versions. "When I was a little wider awake" lacks the elegant smoothness of either the Americanized "when I started functioning a little more smartly" or the more authentically English "when I started functioning a little more sharply."

While one might expect the commercial magazine version to have been the most heavily edited, the available archival and circumstantial evidence point to Wyndham having played a leading role in textual changes between versions. In a letter to his then US literary agent, Frederik Pohl, he writes that "The origin of the triffids was written in as a kind of dangle for the science fiction editorial mind. It doesn't belong, it did not exist before, and it shall disappear" (Beynon Harris, 25 Mar. 1950). ${ }^{16}$ This refers to the most important plot difference between the Collier's abridged serialization and the subsequent novels: in the latter, the plants are created through genetic modification in the Soviet Union, while in the magazine story, set further into the future, their arrival on earth is a result of intergalactic intrigue. ${ }^{17}$ Here, large financial interests which, Masen tells the reader, "in older times would have been called monopolies," have conquered the solar system, driven less "by the fact that men could live on the planets than they were in the wealth the planets produced" $(R T, 6$ Jan. 1951, 64). The first incarnation of the tale, then, has a more recognizably generic sf future setting, and the exploration of the solar system is presented as being driven by economic exploitation of off-world resources. This closely accords with Wyndham's views on the link between the history of European colonialism and the growth of corporate multinational 
power in his space-opera novel The Outward Urge (1962). In it, he explicitly refers to Pope Alexander VI's division of the New World between the Castilians and the Portuguese following the return of Columbus to Spain via Lisbon in 1493 (147). ${ }^{18}$

In $R T$, space colonization is similarly linked to the early colonial exploration of South America, as triffids are discovered growing in other valuable vegetation on Venus by an Argentinian plantation owner. In an act of industrial sabotage, the oil conglomerate "Arctic \& European" shoots down a rocket full of triffid seeds in the earth's atmosphere. In contrast, in both versions of $D T$, these references to far-future space colonies and rocket power are replaced with terrestrial, Cold War allusions: a Soviet fighter jet is blamed for shooting down a plane carrying the triffid seeds.

This difference has important implications regarding Wyndham's attitude towards evolutionary theory. Moore argues that what he terms the "Wyndham strategy"-essentially what the author himself termed "logical fantasy"employs an evolutionary philosophy that can be traced through H.G. Wells to Thomas Henry Huxley, Wells's teacher in the mid-1880s. Moore distinguishes this from the pure "scientific" theory of Darwin, arguing that Huxley had "ambivalence towards the idea of progress" in evolutionary terms ("Utopian" 47). In a discussion of one of Wyndham's later novels, he explains that Huxley divided the world between the "state of nature" and the "state of Art," which transcends the natural world. Moore therefore argues that

For Wyndham, following Huxley, the theory of evolution reveals a thoroughly Hobbesian state of nature, as anarchistic, in the pejorative sense, as any conservative nightmare of revolution. Nature is little short of chaos, with only humanity to bring any meaning to the maelstrom. $(53)^{19}$

For this argument to hold water, Wyndham's understanding of evolutionary theory must be based on an indirect reading (through Wells) of some very outdated texts. Furthermore, it rests on a false dichotomy between the "political" Huxley and the "apolitical" Darwin. In fact, in The Descent of Man (1871) Charles Darwin had contributed to what Peter Bowler terms a liberal "progressionist model of human mental and cultural evolution" (211). But he was also "aware of the problems posed by the concept of progress" (220) and understood evolution was not a linear but "a branching process" (211). The theories of Huxley and Darwin both "incorporated elements of liberal ideology" (184), and the political commitment of both men to Gladstonian liberalism is unquestionable. Indeed, in March 1877, Huxley visited Darwin at his home in the company of a group led by Liberal Party grandee John Lubbock that included William Gladstone himself. According to Darwin's biographer, as "lifelong Liberals" Charles and Emma Darwin "plainly regarded it as 'an honour' and mentioned it subsequently with considerable awe" (Browne 440-41).

Darwin and Huxley may not have universally agreed on matters of evolutionary science or politics, but the differences between their works cannot be reduced to a simple binary of political/non-political. Wyndham's 
reading of evolutionary theory eschews this dichotomy, and in some respects is not Huxleyan at all. For example, in both "Revolt of the Triffids" and The Day of the Triffids, the eponymous plants prosper because they are better adapted to their environment. The triffids' "revolt" is clearly depicted in terms of natural selection: in the words of Anthony Flew, "natural selection does not positively produce anything. It only eliminates, or tends to eliminate, whatever is not competitive" (25). Without the power of sight, humanity is no longer biologically competitive. Natural selection is the part of Darwin's theory that survives most intact today, but it is also the part that T.H. Huxley found hardest to accept (Bowler 184).

When Frederik Pohl pointed out to Wyndham that having a populated Venus created an obvious hole in the plot as Venusians would surely be able to send help to a blindness-stricken Earth, Wyndham responded in his letter of 25 Mar. 1950 that this is what "[c]omes of writing in that bit of phoney [sic] editor and fan appeal too casually." ${ }^{20}$ But the inclusion of a Venus origin for the triffids also cuts out an important part of the more sophisticated engagement with evolutionary theory in the novel texts. The appearance of a successful invasive species from Venus is logically compatible with Darwin's theory of natural selection, whereas the appearance of a new species in the USSR as a result of a human-induced saltation (an evolutionary leap) is compatible with Huxley's views but not those of Darwin. According to Bowler, saltation theories posit that "occasionally individuals may be born so different from their parents that they count as a new species-critics call this possibility the theory of the "hopeful monster'" (5). Darwin rejected this idea on the grounds that "[s]ince we see no evidence of species being formed by sudden saltations today, we may not invoke such discontinuities in the past" (Bowler 9-10). He believed that species change gradually and incrementally.

In the early twentieth century, geneticists rediscovered an 1866 paper written by Gregor Mendel that had been largely ignored, which disproved Darwin's argument in favor of incremental change. Mendel had observed that plant "hybrids, as a rule, are not exactly intermediate between the parental species." Either characteristics are "transmitted entire, or almost unchanged in the hybridisation," which he termed dominant characteristics, or they become latent (recessive characteristics) and may subsequently reappear after one or more generations (Bateson 324). Mendel's work was republished as an alternative theory to Darwinism in 1909. But from the 1920s scientists began to see that rather than being mutually exclusive, Mendelian genetics and Darwinian natural selection could in fact work in conjunction.

The different evolutionary theories that the changes in the Triffids text reflect suggest a considerable familiarity with the history of biology. If Wyndham's knowledge of evolution did come from H.G. Wells, the most likely source is not the early scientific romances, as Moore implies, but rather The Science of Life (1931), which H.G. Wells produced in collaboration with his zoologist son George Philip ("Gip") Wells and T.H. Huxley's grandson, Julian Huxley. Although Wells Senior oversaw and was heavily involved in the project, the two younger men ultimately "brought modern knowledge and 
accuracy to the work" (Mackenzie 357). This included the sections on the new "Mendelism" and "Genetics" in Book 4, "The How and the Why of Development and Evolution."

Wyndham clearly knew about the synthesis of genetics and natural selection as early as his 1933 short story "The Puff-Ball Menace," in which a genetically engineered lethal fungus that looks like an oversized vegetable threatens to overrun England. As a tale of a genetically engineered killer invader plant developed by a foreign power ("Ghangistan"), the story contains the germ of the idea for The Day of the Triffids (see Beynon Harris 24 and Ketterer, "Questions and Answers" 12-13). Here, the plan to destroy England fails because "the stock did not breed true. After two or so generations it was no longer a parasite, but had reverted to a common, saprophytic fungus" (Wyndham, "Puff-Ball" 158). The terms of the scientific explanations of the fungus throughout this story so precisely mirror the explanation of fungi in The Science of Life (288-92) that it must be considered highly likely that Wyndham drew on it as a source text. ${ }^{21}$ By the time that he wrote The Day of the Triffids, Wyndham's engagement with evolutionary theory went beyond what Julian Huxley had called The Modern Synthesis in the subtitle of his 1942 book. Specifically in the British texts of the novel (from Michael Joseph and Penguin), Wyndham demonstrates awareness of another competing view on evolution, with Masen commenting that in Russia

A cleavage of methods and views had caused biology there, under a man called Lysenko, to take a different course. It, too, then succumbed to the endemic secrecy [of the USSR]. The lines it had taken were unknown, and thought to be unsound-but it was anybody's guess whether very successful, very silly, or very queer things were happening there-if not all three at once. (DT 23)

The reference to Trofim Lysenko is telling. Having shot to fame in the Soviet Union in the late 1920s, Lysenko's position was cemented by his “discovery of the 'vernalization' of wheat, a process in which the seeds are frozen so that they will germinate earlier the next spring"; he was ruthless in maintaining his position as an authority on biological research in the USSR (Bowler 246). ${ }^{22}$ But in the 1930s Lysenko rejected Mendelian genetics and with it the Modern Synthesis that had achieved scientific consensus in the West. Instead, he followed late-Enlightenment French evolutionist J.B. Lamarck, who believed that organisms could pass on to their offspring their own acquired characteristics such as improved physical strength to induce rapid evolution. Until he was denounced in the 1950s, Lysenko's adaptation of Lamarckism was used in tandem with horticulturalist Ivan Michurin's hybridization theory of plant grafting as the basis for scientific research across the USSR.

In 1949, shortly after finishing his high-profile appointment as DirectorGeneral of UNESCO, Julian Huxley published two stinging attacks on Lysenko: his book Soviet Genetics and World Science: Lysenko and the Meaning of Heredity and a paper in Nature denouncing Lysenko and his followers as "not scientific in any proper sense of the word" (qtd. in Dronamraju 105). It is likely that Wyndham's reference to the "very queer" 
goings-on in Soviet science was written with this affair in mind, and there is a clear geopolitical dimension to the ambiguous origins of the triffids. Like the Soviet nuclear program, the creation of the triffids owes a debt to both Western post-Darwinian science and its Soviet counterpart; and anxiety surrounding the plants owes as much to the ease and speed of their proliferation as to their uncanny ambulation and poisonous attacks. As the sleazy salesman Umberto states:

I do not say that there is no sunflower there at all. I do not say there is no turnip there. I do not say that there is no nettle, or even no orchid there. But I do say that if they were all fathers to it they would none of them know their child. I do not think it would please them greatly, either. (DT 24; emphasis in original)

Lysenko is here painted as a latter-day Doctor Moreau, with the triffids serving to demonstrate the plasticity of (plant) life. The lines between selective breeding and induced saltation are blurred by Umberto's reticence. The effect is only slightly sinister, but nevertheless beyond the ken of 1950s science, and plays on contemporary fears of radiation and genetic mutation. If Lysenko's grounding in Lamarckism was "unsound," Soviet science had nevertheless been "very successful" elsewhere when it exploded an atomic device only four years after Hiroshima and Nagasaki.

Interestingly, the five pages in which the murky scientific Soviet origins of the triffid plant are laid out are absent from the US Doubleday/Dolphin text. Here, the troubling mystery surrounding Soviet science is reduced to a single parenthetical clause in which even the proper name "USSR" is avoided in favor of "Russia": "[Umberto] told them that the oil came from Russia (which still hid behind a curtain of suspicion and secrecy)" (DT[a] 26). While the primary reason for cutting this section might have been to reduce the length of the overall text, the choice may also pertain to the political climate in the US, where Joseph McCarthy's star was rising. Wyndham was politically as well as commercially savvy in his approach to editing for different audiences. The pertinent question is not so much why Wyndham made this particular cut, but what the longer passage adds, and why keep it in the British text at all.

Apocalypse and Enlightenment: Challenging the Cosy Catastrophe. This question offers pause for critical reflection on the prevailing critical view of Wyndham's work. In Billion Year Spree (1973), Brian Aldiss dismissed most of Wyndham's postwar novels as "cosy catastrophes," condemning The Day of the Triffids in particular as being "totally devoid of ideas" (294). For good measure, he repeated the "master of the cozy catastrophe" charge in his article on Wyndham for the Oxford Dictionary of National Biography. The epithet stuck and until recently was rarely challenged. As Adam Roberts argues:

[Wyndham's] novels may appear straightforward, and some readers (even some readers who ought to have known better) have been fooled by that. Beneath clearly structured and written narratives of the winds of change blowing across 
the world's landscapes Wyndham has left us with some of the most cunningly wound-up, potently memorable fictions of the century. (ix)

In the opening chapter of The Day of the Triffids alone, Masen as narrator witnesses three suicides (one of which he unwittingly assists, another that he does nothing to stop), along with piles of dead bodies and double infanticide. It is perhaps little wonder that Masen's breakfast consists of four large brandies and a couple of cigarettes: this is not the stuff of bedtime stories. Admittedly, Wyndham does not dwell on the bloody details (curiously little spilled blood is mentioned at all), but neither does he suppress the profusion of violence based on existing social inequalities following the blindness epidemic, including violence against women. Masen often masks the quiet and determined ruthlessness with which he picks his way through the post-comet world, but this should not distract us from the real and continual threat of violence that I argue sits uncomfortably with descriptions of the novel as cosy.

The word catastrophe is as imprecise as "cosy" in describing the novel. Coming from the Greek kata- (meaning down) and strophe (turning), "catastrophe" indicates a specifically rapid downturn. In classical tragedy it is linked to the denouement of the drama. Sudden universal blindness is certainly catastrophic, but the rise of the triffids is slow and linked to the evolutionary processes outlined above. Their survival is not strictly speaking a catastrophe.

The Day of the Triffids conforms to what can be more accurately described as an apocalyptic structure, built around the paradox common to "nearly every apocalyptic text.... The end is never the end" (Berger 5). ${ }^{23}$ The blindnessinducing comets and disintegration of civilization, together with the rise of flesh-eating chimerical monsters that challenge the boundary between plant and animal, is of a piece with biblical apocalypses such as those of Revelations, Enoch, and Daniel, in which species barriers among a variety of animals including lions, birds, and lambs are broken down through their assemblage into chimeras. Apocalypse comes from the Greek apo (away from) and kalupto (concealment). As John Berger argues, "the apocalyptic event, in order to be properly apocalyptic, must in its destructive moment clarify and illuminate the true nature of what has been brought to an end" (5). The omnipotent satellites that Masen hints in chapter 2 were the real cause of the blindness-inducing "comet-debris" (DT 6, 20) are presented as evidence that humanity was attempting to give itself god-like powers of destruction. ${ }^{24}$ Masen's detailed descriptions of the transformation of the metropolis into a necropolis (see Koppenfels 168) and the various attempts he witnesses of people trying to found new communities based on former patterns of life clearly fulfill this apocalyptic function. The narrative follows Masen along a redemptive path toward the utopian community on the Isle of Wight where the novel closes. The difference between catastrophe and apocalypse in The Day of the Triffids is more than a matter of semantics; it colors the way in which we read the narrative as either a "straightforward" nihilistic adventure story fixated on personal survival or, to return to Roberts's suggestion, a richer exploration of 
political and biological themes "wound-up" in an apocalyptic structure of renewal.

Key to this apocalyptic structure is the opposition between an "elect" group of characters at the novel's center who are blessed with both a physical sense of sight and enlightened, rational foresight and the condemned masses who are both literally and figuratively blind. ${ }^{25}$ Wyndham uses this split to explore enlightenment as a religious concept, an intellectual tradition, and a structuring device. He recognized the power of the religious element of the enlightenment metaphor despite his own deep dislike of organized religion, in which he believed spiritual and political power were indelibly linked. ${ }^{26}$

Noting the Enlightenment's frequent imagery of the sun of reason, Koppenfels argues that The Day of the Triffids belongs to a group of

modern versions of dystopia [that] confront individual vision, threatened by retributive extinction, in a more or less allegorical manner with a collective state of blindness, the black parody of man's one-time godlike aspirations and total eclipse of the utopian sun. (156)

The dichotomies between the elect and the condemned, the elite and the masses, are mutually reinforcing in Wyndham's schema. Blindness becomes a punishment for the lack of intellectual perception that permitted the modern militarization of science and technology as well as a means of highlighting how liberal enlightened rationality is bound up with scientific, technological, and social developments. "Since the sun of reason appears as the secular avatar of the all-seeing divine eye, blinding is the appropriate sanction for an act of defiance of its authority" (Koppenfels 156). The logic of religious punishment is paradoxically reframed here: the "sun of reason" metaphor is in the end only a metaphor, and the impulse to punish people for their failure to adhere to the questionable logic of symbols is wholly religious. The blinding, which may paradoxically be termed a divine secular punishment, seems to echo Adorno and Horkheimer's thesis that "myth is already enlightenment; and enlightenment reverts to mythology" (xvi). Following rapid de-industrialization and social regression to pre-Enlightenment modes of living, the population experiences widespread serfdom and slavery. As Roberts puts it, "stripped of the trappings of civilization, human beings are as blindly vegetative as the triffids, and only a few people have foresight, or any kind of sight" (xiii). Bill Masen is from the outset one of the few "enlightened" people in a sea of helplessly "isolated incoherent individuals" (Manlove 47), which he first demonstrates symbolically when he removes the bandages from his eyes to regain his vision.

The split between the rational, enlightened individual and the blind masses structures Wyndham's plot. In the opening chapters Masen journeys around the capital. Inebriation and suicide are rampant among the blind, while religious repentance is conspicuous by its absence. It is significant that Masen and Playton follow a light signal to Senate House, University of London; LaRose notes the similarity to Herbert Mason's famous photo published on 29 Dec. 1940 in the Daily Mail depicting St Paul's Cathedral illuminated (though 
with no apparent source) and surrounded by blacked-out buildings damaged during the Blitz (167). The double maneuver, LaRose continues, is first to "replace spiritual imagery with the ideals of knowledge and a life of the mind" and then to "challeng[e] the idea of the university, information, and truth" by using the very building that housed the Ministry of Information during the War and served as Orwell's inspiration for the Ministry of Truth (168). The University becomes a setting for deception and violence. When Masen and Playton arrive and witness a man firing a machine gun over the heads of the blind crowd pressing at the gate to disperse them, we are left in no doubt as to their ruthless elitism.

Yet later events redefine this ruthlessness as disinterestedly rational. The sighted survivors are split along a moral line: the group who occupy Senate House, led by sociologist Dr. Vorless, intend to leave the blinded to their fate in the dying city in order to find land capable of supporting themselves. The working-class union leader Coker, on the other hand, personifies a more desperate short-term strategy, trying to help as many blinded people to survive for as long as possible by looting the city until all supplies are exhausted. Masen and Josella Playton, while expressing sympathy for the blind, strategically align themselves to the former group. They only stay in London when they are trapped, physically restrained, and then tied to groups of blind foragers. By the time Masen escapes his chains and leaves the city during a virulent pandemic, it is clear that only an enlightened elite can survive. Wyndham implies that in human history evolutionary biology works within the context of social ordering that has its own hierarchies of selection. What Manlove terms Masen's "ruthless practicality and his careful selfishness" makes him adaptable to a world of blindness (49). The most successful characters in the novel have both the physical evolutionary advantage of sight and social privileges in terms of social class, profession, education, and suitable political and moral outlook.

In "Who Survives the Cosy Catastrophe?," Jo Walton contends that the answer to her question is "[a]lmost inevitably nice middle-class white men. They're usually well educated.... They're never rich or titled, but they never grew up in a council house either. They're practical, often scientists, inevitably secular agnostics" (36). While the working-class figure of Coker does not fit this description (although he is able to convincingly pass for middle class when it is to his advantage), Walton does highlight a number of important features of Masen's background that are conducive to his success. Still, Masen puts these social privileges to use, applying to every decision he makes the same logic that structures Wyndham's narrative strategy of logical fantasy. Fully aware of his comparatively privileged background, Masen does not shy away from putting his advantages to use, even at the expense of those less fortunate. Masen is rewarded for his selfishness but the blind are pointedly not: one doomed elderly man clutches "avariciously to his chest two cans of red paint," believing them to be food (DT 50; emphasis added).

Although Masen professes his misgivings at becoming "a low scavenger upon the dead body of the system that had nourished me" (41), he overcomes 
his scruples easily, agreeing with Dr. Vorless that "we have not simply to start building again: we have to start thinking again-which is much more difficult and far more distasteful" (DT 99). Those who lack Masen's intellectual and moral adaptability and cling to traditional values of class, church, and state are doomed. Miss Durrant, for example, who attempts to build a "clean, decent community with standards-Christian standards" at Tynsham Manor, fails to recognize that the contingency and fragility of such standards and values have been exposed (DT 144).

By way of contrast, Masen settles down with Josella Playton in an unconventional extended family on a farm in Sussex, a living situation that echoes the experience of evacuations during WWII (including that of Wyndham's partner Grace Wilson). Masen erects an electric fence to strengthen the homestead as a civilized bulwark against triffid invasions; he makes use of all the modern agricultural methods available to build up food production.

The growing numerical strength of the triffids and their ability to learn, however, brings the adoptive family further woes. These begin with the triffids massing against the perimeter fence to break it down, and they culminate in the final showdown between good and evil, light and (preEnlightenment) darkness, liberal reason and hopeless self-deceiving Realpolitik. An armed group led by the power-hungry Torrence arrives at the farm and attempts to compel its inhabitants to swear fealty to their feudal order, in which the blind masses are kept as serfs and fed on mashed triffid (disparagingly referred to as "cattle food" [228]). After deceiving Torrence and his men and sabotaging their vehicle, the family escapes to join a community of enlightened rationalists on the Isle of Wight. Bulldozing through the farm gate in their half-track truck, they allow the triffids in to surround Torrence's men. The intruders become the sacrificial scapegoats on whom the crimes of past social organization are loaded. In the words of Dennis, one of the members of Masen's extended family group:

I'm suddenly feeling quite kindly towards the triffids. Without their intervention I suppose there would have been a whole lot more of this kind of thing by now. If they are the one factor that can stop serfdom coming back, then good luck to 'em. (DT 230)

The triffids have double-edged political and biological roles within the new world order: on the one hand, they represent a threatening impurity to the enclosed farm community; when they break through the fence, this order is restored by purging the plants by fire. On the other hand, the monstrous nature of their intrusion into the postapocalyptic landscape prevents any reversion to older patterns of living. Ultimately the triffids are a necessary addition to the catastrophic mass blindness, because as a biological competitor they ensure that only the enlightened social order of the Isle of Wight commune can thrive. Torrence, who fails to see the triffids as his ultimate competition for power, is sacrificed for his crimes to the very plants whose 
power he fails to fully appreciate. He goes to his death swearing to resist the invasion of the continental nationalist survivors of his xenophobic imagination.

As a polity, the Isle of Wight commune to which Masen and his family escape is founded on an explicit and voluntary social contract in line with classical liberal political theory, held together through rational self-interest. The novel's closing pages present the paradox of a secular community with a righteous mission to restore the purity of a land invaded by the unclean triffid enemy. As Malcolm Bull notes, in prophetic Jewish and Christian apocalypses the postapocalyptic time to come sees the restoration of the original foundational state of the world through the inclusion of a divine presence; it "is not a world of good rather than evil, but a world prior to that division" (80). The Isle of Wight commune has not yet achieved this unity; but what Masen openly refers to as a "crusade" to fight the triffids and to found a liberal civic identity based on commonly held values ultimately becomes a quest for a total adoption of enlightened liberalism that negates the very concept of "evil." Harpold notes that from the opening line of the book, the novel is framed "in time out of joint" (160). The Blindness ushers in a new epoch that is outside the regulatory temporality of postwar Britain, outside the ordinary sequence of events and construction of history. To Harpold, the novel takes place in a "permanent crisis-stasis of posthistory" (161). I argue that this break in history is a phase within an apocalyptic framework of narrative structure, one that includes a gesture toward the reparation of a world prior to division. The novel ends with the explicit linking of political and religious themes of renewal and enlightenment, as Masen proclaims with Churchillian rhetoric that future generations "will cross the narrow straits on the great crusade to drive the triffids back and back with ceaseless destruction until we have wiped the last one of them from the face of the land that they have usurped" (DT 233). This description of a war against triffids as a religious "great crusade" is telling. The restoration of the liberal secular order requires re-colonization of the British mainland by an army that combines enlightened scientific methods with a self-righteousness drawn from the original medieval crusaders. As with the divine secular punishment of mass blindness, the victory of liberal secularism ironically relies on a religious structure of restoration.

Wyndham's Liberal Anxieties and the British Postwar Settlement. By prophetically casting forward the final victory of the Isle of Wight community onto future generations, Wyndham implies a utopian hopefulness tempered by an element of uncertainty: victory over the triffids remains far from certain. In a letter to Adam Kelso (14 Apr. 1954), Wyndham declared that, in an early draft, he had attempted to write in more detail about the colony, but it "looked like a pill of preaching hidden among the rest." This reflects his wider concern over the postwar British political landscape.

While I do not wish to reduce Masen to a mere authorial self-image, there are parallels between Wyndham's army experiences and the grim attitude that Masen forces himself to adopt in the dying city of London. Forty years old at 
the time of his conscription, Wyndham participated in the D-Day landings. His letters to his partner Grace Wilson from this period, along with his brother Vivian's remembrances, clearly indicate that he found military life lonely and boring, except for the occasions on which it was absurd or traumatic. ${ }^{27}$ In a 29 Jul. 1944 letter to Wilson, he informs her that

You'll have to go on reading me into these arid letters which look so impersonal that I sometimes hate to send them. What else can there be? This that writes them and sends them is not me. It's a kind of abridged version-abridged of all but the extravert part. The introvert must be kept away-he is dangerous and bloody unhappy + hasn't any place here.... So you can see me feeding [sic] (quite well) and looking after the extravert in order to keep a habitation going. But it isn't really alive.

By turning his life into a narrative, Wyndham finds a method to "abridge" his character and forge a hard shell to protect the "intravert" within. Masen similarly presents himself as sympathetic but rationally selfish: "you've got to grow a hide,' I told myself. 'Got to. It's either that or stay permanently drunk'" (DT 69; emphasis in original). For Masen, facing the postcatastrophic world requires growing impervious to scenes of suffering and "abridging" the side of him that might indulge in self-doubt. Yet he has more in common with the blinded than he thinks: he muses that "blindness had shut people into themselves" (DT 45). Moreover, Masen's effort to become less sympathetic and to deal dispassionately with the crisis is more than a question of affect. In shedding his bourgeois scruples he becomes adept at self-deception, telling Playton that "I think we'll have to try to see ourselves not as the robbers of all this, but more as-well, the unwilling heirs to it" (DT 66). In some respects, the problems Masen faces are similar to the circumstances Wyndham himself faced towards the end of the war and its aftermath.

The seismic 1945 British General Election took place while Wyndham was still serving in occupied Europe. On 6 Nov. 1944, he indicated in a letter to Grace Wilson that he favored "Liberalism" (whether this was the Liberal National Party or the Liberal Party is unclear), although he held out no real hope of a turnaround in Liberal election fortunes. By 17 Jun. 1945, however, Wyndham was asking Wilson for the name of their Labour candidate as it "may be useful" to know for his postal vote ${ }^{28}$ Wyndham was caught up in the popular mood of "Wartime unity," which lingered in the "sense of solidarity across the spectrum of class and social groups ... a deeply shared sense of threat and emotional horror arising from experiences such as the Blitz" (Waugh 36). Politicians of all parties felt it incumbent to redress the wartime fall in living standards due to physical destruction, increased mortality, and the war economy. As Alan Sinfield notes, across the mainstream political spectrum "a distinctive ideology of welfare-capitalism was propagated.... The rights to be guaranteed by the state entered the rhetoric of politicians across the spectrum" (16; emphasis in original). Moreover, through the language of "rights," these guarantees would be by their nature Universalist (EpsingAndersen 25). During the War, Churchill's government had commissioned the 
Beveridge Report (1942) and had begun to implement some of its recommendations through the 1944 Education Act and the 1945 Family Allowance Act. Yet Beers, drawing on Stephen Brooke, shows that Labour worked hard over the course of the war

to ensure that the nation recognized Labour's unique commitment to forging a new post-war society, built around the five pillars of security articulated in the Beveridge plan, increased state direction of society, and a new international order laid out in the Atlantic Charter. (671)

Although Labour's commitment to increased state direction of society proved surprisingly popular among voters in 1945, once they were in power liberals such as Wyndham felt increasingly uneasy with the continuation during peacetime of the "pattern of state intervention and popular cooperation to organize production for a common purpose" that the War had exemplified (Sinfield 1). The threats of invasion and the installation of totalitarian government felt very real in the new age of nuclear superpowers.

While the triffids clearly evoke a commonly held sense of threat, Wyndham had misgivings about any feeling of togetherness based solely on uniting against a common enemy. As noted above, the plot of the novel guides the reader through the exploration of different methods of social organization, with the most successful ultimately being the Isle of Wight commune, organized around a shared liberal ideology and the resolve to destroy all triffids. As such, the commune is as liberal and exclusionary as Karl Popper's meritocratic vision in The Open Society and its Enemies. Unlike Britain's postwar settlement, founded on the now sadly eroded principle of universal provision of healthcare, education, and social security by the state, the island community in The Day of the Triffids places strict limits on the support it offers to the blind. The commune is set up by enlightened liberal rationalists for enlightened liberal rationalists, implying strongly that this is the part of humankind really worth saving.

How to Survive a Postapocalyptic Triffid Attack. The Isle of Wight is the final stop on the tour of social organization in Wyndham's "logical fantasy," and while it undoubtedly represents a preferred method of social organization, it also responds to social circumstances. Freedom is both literally and figuratively circumscribed on the tiny island, and the social contract that protects residents from the Hobbesian conditions of the mainland will also lead to tribe-like conditions. As Hubble notes, this is not portrayed negatively: he goes so far as to argue that the need to become more tribal is "one of the central ideas of the book" (94). In moving from the more primitive homestead community to join a community bound by a social contract on the Isle of Wight, Masen, Playton, and their "family" are reentering a public sphere that requires social and economic contributions. In "The Imagination of Disaster," Susan Sontag notes that "the lure of such generalized disaster as a fantasy is that it releases one from normal obligations" (215). In the same passage, she terms the ruination and desertion of cities as "Robinson Crusoe on a worldwide scale." In the immediate aftermath of the blindness-inducing comet, 
Masen behaves in consummately Crusoe-like fashion in considering his bourgeois self-interest. Musing over yet another brandy and cigarette at the Regent Palace Hotel, he reflects upon his position:

What had seemed at times a rather empty existence turned out now to be lucky. My mother and father were dead, my one attempt to marry had miscarried some years before, and there was no particular person dependent on me.... All the old problems, the stale ones, both personal and general, had been solved by one mighty slash.... I was emerging as my own master, and no longer a $\operatorname{cog}$. It might well be a world of horrors and dangers that I should have to face, but I could take my own steps to deal with it-I would no longer be shoved hither and thither by forces and interests that I neither understood nor cared about. (DT 47-48; emphasis added)

As glad as he is not to have parents or dependents to mourn or look after, Masen was already free of such responsibilities before the disaster. On first glance, his sense of release is founded on a sense of rugged individualism that he finds at least temporarily attractive. As Harpold notes, "something is left over or comes back to shadow and possibly rescind the satisfactions of the post-crisis world" (158; emphasis in original). Masen is fortunate to have had an abiding care and interest in the triffids since his early years, for they are the very force attempting to shove him "hither and thither" and against which he will contend for the rest of his days. But he quickly learns that his sense of release and individuality is misplaced: in forming a connection that becomes a relationship with Playton and being pushed from one social experiment to another before settling down for a number of years on Shirning Farm, Masen assumes familial responsibilities almost as quickly as he sheds his wider social ones.

In his own estimation, he is free from state and religious institutions; his mind and his moral compass are both guided by his own (liberal) reason rather than a patriarchal code. In reality, however, from the moment he meets Playton he begins to reproduce these very codes. As part of an enlightened liberal elite, Masen consciously rejects the autonomy he describes feeling in the immediate aftermath of the disaster, becoming instead a cooperative member of a new "family," one that bonds and remains together through intellectual exchange and the shared values of liberal reason. But for all of their enlightened virtues, what really binds this extended "family" is the communal rearing of children within a hierarchy only slightly altered from the days before the disaster. And while they initially view the move to the Isle of Wight as a regrettable expedient, it is really only a short step from the familial obligations of their existing extended family to the social and economic obligations of a larger tribal community.

The rousing Churchillian rhetoric of the final page of the novel therefore rings a little hollow. The "crusade" against the triffids demonstrates the superiority of the sociopolitical organization of the Isle of Wight and as such is far from progressive. Furthermore, the "ceaseless destruction" of this quest "doesn't seem that cozy" (Harpold 160). Masen effectively states that his intention is to win by military conquest, a tactic redolent of the Victorian 
colonialist attitude exhibited by liberals of a century earlier, such as John Stuart Mill. ${ }^{29}$ The drive toward a pre-triffid British unity superior to the "tamed" but threatening world of the early Cold War is an attempt to valorize liberalism as Edenic, echoing the apocalyptic structure to which earlier sections of the narrative belong. Importantly in this respect, the defeat of the triffids is to be brought about through biochemical research (DT 220). The political and scientific visions of the novel's end are a flawed attempt to answer demanding postwar social anxieties and to square the circle between evolutionary theory and prewar British liberalism. The viability of liberal responses to the postwar era is dependent upon incorporation of the idea that, as Wyndham put it in his next novel, "life in all its forms is strife" (Kraken 180). Ultimately, the novel's primary didactic message is that only an elite able to mobilize a specific liberal ideology couched in scientific rhetoric can flourish in the postapocalyptic world. In The Day of the Triffids, survival requires both the empirical sense-experience of sight to gain new knowledge and dispassionate liberal reason to adapt to social change.

\section{NOTES}

1. I thank Dr. Stacy Gillis, Newcastle University, for her helpful comments on early drafts of this article and Professor David Ketterer for his comments and help with additional archival material. I am also grateful to my reviewers for their helpful suggestions.

2. For a list of adaptations of The Day of the Triffids, see Harpold (162 n.4).

3. Herbert Asquith was the Prime Minister under whom a raft of reforms, including the introduction of National Insurance and universal pensions, were introduced in the years before World War I. William Beveridge was a former Fabian and ex-director of the London School of Economics and a wartime temporary civil servant. He chaired the committee that produced the Report on Social Insurance and Allied Services, now known as The Beveridge Report (1942), which proposed the creation of the National Health Service. He subsequently became an MP for the Liberal Party, while Atlee's Labour Government created the NHS.

4. Roland Wymer and Owen Webster argue the case that Wyndham's novels are full of unsettling and non-"cosy" ideas, while L.J. Hurst argues that "The Day of the Triffids has often been treated as a horror story devoid of ideas rather than an S.F. novel full of ideas" (4). More recently, Nicole LaRose argues that "the novel is ripe with complex philosophical ideas, especially if we focus on the novel's historical understanding of postwar Britain" (165). Terry Harpold argues that the triffids disrupt the "oppositional logic" (158) of Aldiss's framework, and Graham Sleight notes that while $D T$ "[c]ontains such moments" as characterize Aldiss's conception of the cosy catastrophe, "it's anchored by many others" that do not.

5. The Chrysalids was released as Re-Birth in the US. There are fewer differences between the US and UK editions of this novel, compared to the extensive changes in The Day of the Triffids or Wyndham's 1953 novel The Kraken Wakes (US title: Out of the Deeps).

6. Wyndham's prewar writing, mainly under the names John Beynon Harris and John Beynon, included stories in US detective and sf pulps as well as British magazines and the published novels Foul Play Suspected (1935), The Secret People (1936), and Stowaway to Mars (1936). His writing had been an unsustainable, unreliable source of income. Much about Wyndham's life before and after the War remains a mystery. 
David Ketterer has recently suggested that such mysteries extend even to the year and place of his birth, which he may have altered from 1902 to 1903 because he was born out of wedlock ("When and Where?").

7. In his follow-up novel The Kraken Wakes, Wyndham took this a stage further by choosing as narrator a journalist claiming explicitly to be writing a documentary.

8. Famous examples of such works include Edward Bellamy's Looking Backward: 2000-1887 (1887), William Morris's News From Nowhere (1890), Jerome K. Jerome's short anti-socialist satire "The New Utopia" (1891), and H.G. Wells's The Sleeper Awakes (1910). According to Mark Kermode, director Danny Boyle has stated that the scenario of waking in hospital to an altered world directly inspired Alex Garland's screenplay for Boyle's film 28 Days Later (2002).

9. "Verne asked himself: what excitement can we get out of this invention? Wells enquired: what effect, if it could come about, would this state of affairs have on people?" (Wyndham Archive [WA in subsequent Notes]). Hence, for example, Verne's 20,000 Leagues Under the Sea (1870) uses an invention (Captain Nemo's submarine) as a vehicle primarily to explore the ocean's depths, whereas Wells's The War in the Air (1908) uses the invention of flying machines as a means to dramatize political tensions among Britain, Germany, and the US, and to consider the effects of aerial warfare on civilian populations-life "in the air" is not really a focus of the text. In a questionnaire for Kingsley Amis, Wyndham claimed that "Wellsian SF is what I mainly attempt" (WA).

10. It is interesting in this respect that the influence of Wells is not consistent among the three published versions of the Triffids text: the direct reference to "the country of the blind" which appears in both the US Doubleday/Dolphin text (69) and the UK Michael Joseph/Penguin text (67) is cut from the serialization "The Revolt of the Triffids"-perhaps because Wyndham considered Masen's discursion on the correct translation of the Latin patria to be too intellectual for the more hardboiled presentation of his character in the magazine. The scope and extent of the changes in the Collier's text indicate Wyndham's ready willingness to adhere to publishers' wishes.

11. Ketterer argues that the novel version of The Day of the Triffids is set in 1976 ("Revised and Updated Introduction to Plan for Chaos"). He reasons that many textual hints in Plan for Chaos point to its being intended as a prequel to The Day of the Triffids. Wyndham once attempted to write a sequel to the latter, of which two fragments exist in the Wyndham Archive. In these fragments, which are set on a remote Pacific island in 2006, the blindness-causing comets occurred exactly thirty years earlier. In contrast, the Collier's text is set in the far future, and as a result the critique of the postwar era loses some of its force.

12. For a detailed discussion of sf and Communism in the Cold War era, see Seed.

13. In a letter of 9 May 1950 to his agent Frederick Pohl, held at Syracuse University Special Collections, Wyndham informs Pohl that he sent the manuscript via surface mail on 4 May (in good time for the 1 June deadline to which he was committed).

14. Like Wyndham's "Revolt of the Triffids," Jack Finney's story on which Don Siegal's film of Invasion of the Body Snatchers was first published in Collier's.

15. Further confusion arises from the fact that a Popular Library US edition was published in 1952 under the title Revolt of the Triffids with one of the original Collier's illustrations on the cover. This edition follows the Doubleday Day of the Triffids text, however, and not that of Collier's "Revolt of the Triffids." Reader Paul Thompson on his fan-site "The Reader's Guide to The Day of the Triffids" estimates the length of the 
abridged American version to be around 79,500 words, and the UK version to be 90,500 words. This is a slightly greater difference than bibliographer Phil StephensenPayne's estimate that the US text is abridged by "some ten thousand words" (116).

16. I am grateful to David Ketterer for showing me a photocopy of this letter.

17. For a detailed investigation of the original inspiration for the idea of mobile, deadly plants, see Ketterer, "Genesis."

18. Columbus's return caused a diplomatic dispute over the newly discovered territories. Pressed to intervene, the Spanish-born Pope Alexander VI issued a Bull entitled Inter Caetera, popularly believed to have divided up the New World, but which was actually "a statement on the nature of Christian-infidel relations and on the responsibility of the Pope to protect the infidels and convert them to Christianity" (Muldoon 169). Worrying that his return to traditional space-based sf in The Outward Urge might alienate some of the fan base he had built up through novels from The Day of the Triffids to The Midwich Cuckoos, Wyndham styled this book as written by "John Wyndham and Lucas Parkes"-two of his middle names.

19. This argument, which Moore deals with in his 2003 article $(47,53)$, is expanded upon in much greater detail in his unpublished $\mathrm{PhD}$ thesis (Liverpool, 2007), where it is also applied to earlier novels including The Day of the Triffids, but particularly The Kraken Wakes.

20. Wyndham writes to Pohl: "Your observation about expecting intervention from Venus had not occurred to me, but now you mention it, I can well see how it would arise."

21. The sudden failure of the puff-ball invasion, meanwhile, is strikingly similar to the fate of the Martian invaders in Wells's The War of the Worlds (1898).

22. Lysenko had a tendency to take this to extremes: even Stalin, on whose patronage he relied, found his claim in a draft paper that "any science is classorientated in its very nature" nonsensical. In the margin next to it, Stalin scrawled “"HA-HA-HA!! AND WHAT ABOUT MATHEMATICS? AND WHAT ABOUT DARWINISM?" (Rossianov 732).

23. Indeed, as Derrida has argued, the End is fundamentally unrepresentable in narrative terms: it entails the loss of the whole human "archive and symbolic capacity" by which individual deaths are normally culturally assimilated (28). Not only would no one be left to remember, but representation itself would vanish. In Daniel Pick's words, "whilst it can be anticipated according to the terms of our current language and memory, its actual occurrence would overrun and obliterate the very possibility of its own retrospective representation" (7-8).

24. David Ketterer pointed out to me in correspondence that these satellites are imported from Wyndham's novel Plan for Chaos, written around 1948 but not published until 2009.

25. A similar confluence between spiritual and political power occurs in The Chrysalids. Set a thousand years after a nuclear holocaust, The Chrysalids tells the story of a group of telepathic teenagers representing a new form of humanity who are persecuted by their superstitious religious community for being "mutants." In this community, the religious authority to condemn crops, livestock, and humans as "mutant" confers political and economic power alongside spiritual power. Here, the telepathic teenagers and a woman from "Sealand" who rescues them are the "elect," while the religious community and mutant outcasts who struggle to survive in the forest are the condemned. 
26. With the understated humor characteristic of his correspondence, Wyndham once wrote of religions, "power tends to corrupt them. Have a suspicion that they may be the Achilles' heel of humanity" (WA; rpt. Ketterer, "Questions and Answers" 6).

27. Wyndham's wartime letters to Grace Wilson are held in the Wyndham Archive, University of Liverpool. For the memoir of his brother written by Vivian Beynon Harris, see "[My Brother] John Wyndham: A Memoir."

28. I am grateful to David Ketterer for alerting my attention to this reference to the election.

29. In the same Commons speech in which Mill is often said to have coined the term "dystopian," he said of colonial Ireland that "I maintain that there is no country under Heaven which it is not possible to govern, and to govern in such a way that it shall be contented" (Hansard Commons 12 Mar. 1868, vol. 190, c. 1523). According to Alan Ryan, Mill searched for a totalized system of laws in every field he studied, government no less than ethics (xi-xii). Ryan quotes Mill's diary of 1854 in support of this claim.

\section{WORKS CITED}

Adorno, Theodor W., and Max Horkheimer. Dialectic of Enlightenment. 1947. Trans. John Cumming. London: Verso, 1997.

Aldiss, Brian W. Billion Year Spree: The History of Science Fiction. London: Weidenfeld, 1973.

. "Harris, John Wyndham Parkes Lucas Beynon [John Wyndham] (1903-1969)." Oxford Dictionary of National Biography. Ed. Lawrence Goldman. Oxford, UK: Oxford UP, 2004. Online. 23 Mar. 2015.

Bateson, William. Mendel's Principles of Heredity. Cambridge, UK: Cambridge UP, 1909.

Beers, Laura. "Labour's Britain: Fight for it Now!” Historical Journal 52.3 (Sep. 2009): 667-95.

Berger, John. After the End: Representations of Post-Apocalypse. Minneapolis: U of Minnesota P, 1999.

Beynon Harris, John. Letter to Frederik Pohl. 25 Mar. 1950. MS. Frederik Pohl Papers, Special Collections Research Center, Syracuse University, New York.

Beynon Harris, Vivian. "[My Brother] John Wyndham: A Memoir." Ed. David Ketterer. Foundation: The International Review of Science Fiction 75 (Spring 1999): 5-50.

Bowler, Peter J. Evolution: The History of an Idea. 3rd ed. Berkeley: U of California $\mathrm{P}, 2003$.

Browne, Janet. Charles Darwin. Vol. 2: The Power of Place. 2002. London: Pimlico, 2003.

Bull, Malcolm. Seeing Things Hidden: Apocalypse, Vision and Totality. London: Verso, 1999.

Derrida, Jacques. "No Apocalypse, Not Now (Full Speed Ahead, Seven Missiles, Seven Missives)." Trans. Catherine Porter and Philip Lewis. Diacritics 14 (Summer 1984): 20-31.

Dronamraju, Krishna R. If I Am to be Remembered: The Life and Work of Julian Huxley With Selected Correspondence. Singapore: World Scientific, 1993.

Epsing-Andersen, Gøsta. The Three Worlds of Welfare Capitalism. Cambridge, UK: Polity, 1990.

Flew, Anthony. Darwinian Evolution. London: Paladin, 1984. 
Harpold, Terry. "The End Begins: John Wyndham's Zombie Cozy." Generation Zombie: Essays on the Living Dead in Modern Culture. Ed. Stephanie Boluk and Wylie Lenz. Jefferson, NC: McFarland, 2011. 156-64.

Hubble, Nick. "Five English Disaster Novels, 1951-1972." Foundation: The International Review of Science Fiction 34 (Autumn 2005): 89-103.

Hurst, L.J. "We Are the Dead: The Day of the Triffids and Nineteen Eighty-Four." Vector 113 (Aug.-Sep. 1986): 4-5.

Huxley, Julian. Soviet Genetics and World Science, Lysenko and the Meaning of Heredity. London: Chatto \& Windus, 1949.

- Evolution: The Modern Synthesis. Cambridge, MA: MIT, 2010.

James, Edward. Science Fiction in the 20th Century. Oxford, UK: Oxford UP, 1994.

Kermode, Mark. “A Capital Place for 'Panic Attacks.'” Observer 6 May 2007. Online. 22 April 2014.

Ketterer, David. "The Genesis of the Triffids." New York Review of Science Fiction 16.7 (Mar. 2004): 11-14.

- "John Wyndham: The Facts of Life Sextet." A Companion to Science Fiction.

Ed. David Seed. Oxford: Blackwell, 2005. Online. 19 July 2014.

—. "Questions and Answers: The Life and Work of John Wyndham." New York Review of Science Fiction 16.7 (Mar. 2004): 1, 6-10.

- "The Revised and Updated Introduction to Plan for Chaos by John Wyndham.” HUBbub Blog. 17 Nov. 2009. Online. 9 Aug. 2013.

—. “'Vivisection': Schoolboy 'John Wyndham's' First Publication?” SFS 26.2 (Jul. 1999): 303-11.

—. "When and Where was John Wyndham Born?" Foundation: The International Review of Science Fiction 42 (Summer 2012/13): 22-39.

Koppenfels, Werner von. "These Irritant Bodies: Blinding and Blindness in Dystopia (A Powerful Parable Found in the Narratives of Cyrano de Bergerac, Swift, Wells, Wyndham, and Saramago).” Cambridge Quarterly 33.2 (Jan. 2004): 155-72.

Langford, Barry. Introduction. The Day of the Triffids by John Wyndham. London: Penguin, 1999. i-xvii.

LaRose, Nicole. "Zombies in a 'Deep, Dark Ocean of History': Danny Boyle's Infected and John Wyndham's Triffids as Metaphors of Postwar Britain." Generation Zombie: Essays on the Living Dead in Modern Culture. Ed. Stephanie Boluk and Wylie Lenz. Jefferson, NC: McFarland, 2011. 165-81.

Mackenzie, Norman and Jeanne. H.G. Wells: A Biography. New York: Simon, 1973.

Manlove, C.N. "Everything's Slipping Away: John Wyndham's The Day of The Triffids." Journal of the Fantastic in the Arts 4 (1991): 29-53.

Moore, Matthew. "A Critical Study of John Wyndham's Major Works." Diss. U of Liverpool, 2007.

- "Utopian Ambivalences in Wyndham's Web." Foundation: The International Review of Science Fiction 32 (Autumn 2003): 47-56.

Muldoon, James. "Papal Responsibility for the Infidel: Another Look at Alexander VI's 'Inter Caetera.'” Catholic Historical Review 64.2 (Apr. 1978): 168-84.

Pick, Daniel. War Machine: The Rationalization of Slaughter in the Modern Age. New Haven, CT: Yale UP, 1993.

Pooter [Alex Hamilton]. "Talking to John Wyndham." Times Saturday Review 16 Mar. 1968: 23.

Popper, Karl. The Open Society and its Enemies. 1945. Abingdon: Routledge, 2011.

Roberts, Adam. Introduction. The Day of the Triffids by John Wyndham. London: Folio, 2010. ix-xiii. 
Rossianov, Kirill O. "Editing Nature: Joseph Stalin and the 'New' Soviet Biology." Isis 84.4 (Dec. 1993): 728-45.

Ryan, Alan. The Philosophy of John Stuart Mill. London: Macmillan, 1970.

Sawyer, Andy. "Midwich Abandoned: An Unpublished 'Sequel' by John Wyndham; or, 'It Comes of Being a Hybrid." A Celebration of British Science Fiction. Ed. Andy Sawyer, Andrew M. Butler, and Farah Mendlesohn. Liverpool: SF Foundation, 2005. 7-17.

Seed, David. American Science Fiction and the Cold War: Literature and Film. Edinburgh: Edinburgh UP, 1999.

Sinfield, Alan. Literature, Politics, and Culture in Postwar Britain. Oxford, UK: Blackwell, 1989.

Sleight, Graham. "Yesterday's Tomorrows: John Wyndham." Locus Magazine (Dec. 2010). Online. 8 April 2015.

Sontag, Susan. Against Interpretation and Other Essays. 1966. New York: Picador, 2001.

Stephensen-Payne, Phil. John Wyndham: Creator of the Cosy Catastrophe. A Working Bibliography. 3rd ed. Leeds: Galactic Central, 2001.

Thompson, Paul. "The Reader's Guide to The Day of the Triffids." 2007. Online. 11 Nov. 2013.

Walton, Jo. "Who Survives the Cosy Catastrophe?" Foundation: The International Review of Science Fiction 34 (Spring 2005): 34-39.

Waugh, Patricia. "The Historical Context of Post-War British Literature." The PostWar British Literature Handbook. Ed. Katherine Cockin and Jago Morrison. London: Continuum, 2010. 35-56.

Webster, Owen. "John Wyndham as Novelist of Ideas." SF Commentary 44/45 (Dec. 1975): 39-58.

Wells, H.G. "The Country of the Blind." 1904. Selected Short Stories. London: Penguin, 1958. 123-46.

- In the Days of the Comet. 1906. London: Hogarth, 1985.

. The Sleeper Awakes. 1910 [rev. When the Sleeper Awakes (1899)]. Ed. Patrick Parrinder. London: Penguin, 2005.

- Julian Huxley, and George Philip Wells. The Science of Life. 1931. 9 vols. New York: Literary Guild, 1934.

Wymer, Rowland. "How 'Safe' Is John Wyndham? A Closer Look at His Work, with Particular Reference to The Chrysalids." Foundation: The International Review of Science Fiction 55 (Summer 1992): 25-36.

Wyndham, John. "Account from Waimori, March, Anno 25 (A.D. 2001)." Fragment of story. MS. John Wyndham Archive, U of Liverpool.

. The Chrysalids. London: Penguin, 1958.

- Correspondence between John Wyndham and Sam Moskowitz: Questionnaire and Response. 1963. MS. Wyndham Archive, U of Liverpool.

. The Day of the Triffids (a). Garden City, New York: Doubleday/Dolphin. 1951.

- The Day of the Triffids. Introduction by Barry Langford. London: Penguin, 1999.

The Kraken Wakes. London: Penguin, 1955.

- Letter to Adam Kelso, Esq. 14 Apr. 1954. Carbon copy of MS. Wyndham Archive, U of Liverpool.

. Letter to Frederik Pohl. 6 Nov. 1950. MS. John Wyndham Archive, U of Liverpool. 
Letter to Grace Wilson. 29 Jul. 1944. MS. Wyndham Archive, U of Liverpool.

. Letter to Grace Wilson. 6 Nov. 1944. MS. John Wyndham Archive, U of Liverpool.

. Letter to Grace Wilson. 17 Jun. 1945. MS. John Wyndham Archive, U of Liverpool.

. The Midwich Cuckoos. 1957. London: Penguin, 1960.

. The Outward Urge. 1959. London: Penguin, 1962.

Plan for Chaos. Liverpool, UK: Liverpool UP, 2009.

- "The Puff-Ball Menace." [First published in Wonder Stories, ed. Hugo Gernsback, in Oct. 1933 as "Spheres of Hell" and signed John Beynon Harris.] Wanderers of Time. London: Coronet, 1973. 135-58.

. Questionnaire for Kingsley Amis. 1958. MS. Wyndham Archive, U of Liverpool.

. "The Revolt of the Triffids." Collier's, 6 Jan. 1951: 9-11, 63-67; 13 Jan 1951: 28-29, 50-55; 20 Jan. 1951: 36-37, 50-55; 27 Jan. 1951: 24-25, 38-44; 3 Feb. 1951: 28-29, 50-56.

- Stowaway to Mars (formerly Planet Plane [1936]). London: Coronet, 1972. Waimori Fragment (II). MS. John Wyndham Archive, U of Liverpool.

. "Wells V[ersus]. S-F." Unpublished Article. Undated. TS. John Wyndham Archive, U of Liverpool.

, and Lucas Parkes. The Outward Urge. Harmondsworth: Penguin. 1962.

\section{ABSTRACT}

In John Wyndham's breakthrough novel The Day of the Triffids (1951), the dissolution of the modern nation-state as a result of mass blindness is used as a springboard to explore a range of social and cultural anxieties and political concerns of the postwar world. In this postapocalyptic landscape, the narrative leads the reader through descriptions of successive methods of social organization, questioning the assumptions and values of each type. The novel is also notable for Wyndham's questioning of the underlying scientific ideas, including competing theories of evolution and genetic mutation, of the mid-twentieth century. Through analysis of the three published versions of the novel's text and archival material, I consider the development of Wyndham's Wellsian style, his apocalyptic narrative structure, his political ideas, and his understanding of evolutionary theories. 